\title{
The Influence of Humor Styles on The Sense of Belonging among University Students
}

\author{
Mohammad Saipol Mohd Sukor*, Siti Aisyah Panatik, Nurul Farhana Nordin \\ School of Human Resource Development and Psychology, Faculty of Social Sciences and Humanities, Universiti Teknologi Malaysia, 81310 UTM Johor \\ Bahru, Johor, Malaysia \\ *Corresponding author: mohammadsaipol@utm.my
}

Article history: Received: 17 April 2019 Received in revised form: 18 July 2019 Accepted: 30 September 2019 Published online: 31 December 2019

\begin{abstract}
The sense of belonging is a strongly human desire, but it is less explored by past researchers. The sense of belonging exists when people in a group or community were taking care and supporting each others. In order to further explore the predictors of the sense of belonging, this study is conducted to identify the influence of humor styles behavior on the sense of belonging. A total of 108 local postgraduate full-time students in a public university in Malaysia were involved in the study. The instruments used were Humor Styles Questionnaire (HSQ) and Psychological Sense of Belonging (SOBI-P). The result from regression analysis shows that there are significant influences of humor styles behavior on the sense of belonging among postgraduate students. It was found that the self-enhancing humor will increase the sense of belonging, whereas the aggressive humor will decrease the sense of belonging among postgraduate students. Overall, this study support Martin's theory about the role of adaptive and maladaptive humor in the social relationship especially in the context of educational environment.
\end{abstract}

Keywords: Sense of belonging, affiliative humor, self-enhancing humor, aggressive humor and self-defeating humor

\begin{abstract}
Abstrak
Perasaan kekitaan ialah suatu keinginan yang kuat dalam diri manusia, tetapi ianya kurang diterokai oleh pengkaji-pengkaji lepas. Perasaan kekitaan wujud apabila individu dalam sesuatu kumpulan atau komuniti saling mengambil berat dan memberi sokongan antara satu sama lain. Untuk meneroka dengan lebih lanjut mengenai peramal-peramal kepada perasaan kekitaan, maka kajian ini dijalankan untuk mengenal pasti pengaruh gaya tingkah laku humor terhadap perasaan kekitaan. Seramai 108 orang pelajar tempatan pasca ijazah sepenuh masa di sebuah universiti awam di Malaysia terlibat dalam kajian ini. Instrumen-instrumen yang digunakan ialah Humor Styles Questionnaire (HSQ) dan Psychological Sense of Belonging (SOBI-P). Hasil analisis regresi menunjukkan bahawa terdapat pengaruh yang signifikan bagi gaya humor terhadap perasaan kekitaan dalam kalangan pelajar pasca siswazah. Didapati bahawa humor self-enhancing akan meningkatkan perasaan kekitaan, manakala humor agresif akan mengurangkan perasaan kekitaan dalam kalangan pelajar pasca ijazah. Secara keseluruhannya, kajian ini menyokong teori Martin mengenai peranan humor adaptif dan maladaptif dalam perhubungan sosial terutamanya dalam konteks persekitaran pendidikan.
\end{abstract}

Kata kunci: Perasaan kekitaan, humor afiliatif, humor self-enhancing, humor agresif dan humor self-defeating

(C) 2020 Penerbit UTM Press. All rights reserved

\subsection{INTRODUCTION}

The sense of belonging has been recognized as one of the human needs just like the need for food and shelter (Westerfield, 2009). It is crucial in seeing the value of life and coping with intense emotions caused by different psychological state such as stress, depression and anxiety (Hall, 2014). The Sense of belonging comes from the quotes that "no man is an island, entire of itself" which bring the understanding that every man has either direct or indirect connections to other men, women and children in this world (Jones, 2009). Basically, the sense of belonging refers to the feeling of being accepted, valued, included and encouraged by people in a social environment or community (Hall, 2014). People may find belonging either with friends, family, school, university, club, organization or even through social media.

Previous research has shown the significant part of sense of belonging in some aspect of human life, especially in educational context. For science, technology, engineering, and mathematics (STEM) graduate students from different background, a sense of belonging can have a concrete effect on the academic achievement and crucial for their career development (Langin, 2019). Students with greater sense of 
belonging are more likely to have positive quality of life. Meanwhile, students who lack the sense of belonging are more likely to experience greater intensity in their reported psychological symptoms (Jones, 2009).

The sense of belonging among college students also predicted better physical health due to support from peers and teachers (Hale, Hannum \& Espelage, 2005). Another study conducted by Cedeno (2010) found that student's sense of belonging predicted problem behaviors in school, fostering academic growth and enhancing student's performance on examination and emotional competencies in urban, early and late elementary school. Better sense of belonging produce caring and supportive school environment, which is not only a precondition for student's academic achievement but also a necessary predictor of positive development including social and emotional competencies to which academic competence is inextricably tied (Comer, 2004). A sense of belonging is now understood to be an important need for students to function well in learning environments. It has a direct link to a student's academic motivation and belief in their ability to succeed (Todman \& Hume, 2018).

A considerable amount of study have been conducted on the consequences of the sense of belonging such as student's adjustments, motivation, achievement, psychological symptoms, mental health, problem behavior in school, attachment anxiety, stress and depression (Anderman, 1999a; Blonstein, 2004; Cedeno, 2010; Davis, 2003; Freeman, 2005; Goodenow \& Grady, 1993). Since then, the sense of belonging was known to be necessary to the students overall well-being and commitment. However, there is a lack of research focusing on the factors that may influence the sense belonging which makes the researchers unable to fully predict the sense of belonging among students and how to increase the positive psychological state in the learning environment. Obviously, less is known theoretically and empirically about the antecedents of sense of belonging. Therefore, while the sense of belonging considered as one of the human need, more studies with varied factors, populations and cultures are still needed (Jones, 2009). It will provide more significant explanation on the factors that bring people together.

The sense of belonging has been explored more often among students in primary and secondary school rather than students in college or university (Jones, 2009). Thus, limit the understanding on how the sense of belonging develops and evolves over time particularly among students in higher education. Although there are some literature and research conducted in higher education, but it tends to focus on students informal interactions and traits rather than contextual factors that might be related to student's voluntary or involuntary withdrawal from university (Freeman, 2005; Singh, 2018). Contextual factors would be referred as the characteristics of learning environment that manipulate the efficiency of the learning process which included community and school factors. One of the possible factors that may influence the sense of belonging as it relates to motivation, achievement, pre-social skills and student's engagement to the university is humor.

Mak and Deneen (2012) define humor as an utterances on the basis of para-linguistic and discoursed clues as intended by the speakers to amuse and perceived to be amusing by at least some participants. Humor is a form of communication that used by an individual to bring forth amusement or laughter and to relief from stress (Hawkins, 2008). Besides intended to amuse, humor may also serve a lot of functions in human life (Lang \& Lee, 2010). Humor may at first seem to be a simply lighthearted and enjoyable form of communication, but later it may actually take on various emotional and cognitive functions (Martin, 2006).

Humor can be used for newcomer's integration into the new environment and an effective way to mold newcomers into the normative ways of doing things (Mak \& Deneen, 2012). Previous literature supported the use of humor as a means of coping with the intense situation and as a form of communication that promote cohesiveness, build consensus, deliver messages across power and authority, make the situation less threatening and promote change (Hawkins, 2008; Cruthirds, 2006; Sukor et al., 2018). It is also related to interpersonal adjustment and emotional well-being among university students (Fitts, Sebby \& Zlokovich 2009). Lefcourt, Davidson, Prkachin and Mills (1997) stated that positive effects derived from humor result more from its ability to increase social cohesion and acceptance among students in higher education.

With respect to different functions of humor in the social relationship especially in learning environment. This study aims to investigate the impact of humor on the sense of belonging among postgraduate students. It will provide the useful information about the possible pathways by which humor may affect broader development of the student's relationship with the university. Exploring the impact of humor on the sense of belonging is important as these associations seldom being found in literature. Thus, the current study aims to determine the levels and also the causal relationship between humor styles and the sense of belonging among the students in a public university in Malaysia.

\subsection{LITERATURE REVIEW}

The need to be accepted by others in a social environment can be understood through Maslow's Hierarchy of Need Theory. Abraham Maslow (1954) proposed a theory of human's need that has far stood the test of time and still considered relevant and practical until today. This theory explained the human basic needs which predict the motivation and life satisfaction. It started with the physiological needs, followed by the needs of safety, belonging and loves, esteem and finally the need for self-actualization (Huitt, 2004). Maslow describes the belonging needs as, "hunger for the affectionate relationship with people in general, namely for a place in his group or family" (Maslow, 1954, p43). It shows that by fulfilling this need can enhance one's own life satisfaction. In other words, to avoid problems such as loneliness, depression, and anxiety, it is important for people to feel loved and accepted by other people (Cherry, 2018). In educational context, the sense of belonging is an integral part of keeping the students, promoting academic engagement, motivation and achievement (Goodenow, 1993a). Most of the physiological and safety needs were met in the educational setting, thus the next need that often becomes the source of difficulty for students and appears to have less scientific information on literature is the need of belonging (Jones, 2009).

The concept of sense of belonging in the current study is largely influenced by the perspective posited by McMillan and Chavis (1986) as a"sense of community". Within their framework, the bonding to a community consisted of five components such as membership, influence, integration, fulfillment of needs and shared emotional connection. All the components were used as a guide to understand and to measure the student's feeling of acceptance, support, inclusion and respect in the learning environment (Goodenow, 1993b). They were further comprised by Hagerty and Putesky (1995) into three categories or constructs such as peer acceptance, teacher support and general sense of belonging. The three constructs used in this study to measure student's sense of belonging to the university. 
According to Maslow (1954) in order to be healthy and avoid sickness, people need love from where they belong. Therefore, more research needed to explore different factors that influence the sense of belonging. According to Cruthirds (2006) several observational studies have shown that humor is a social "lubricant" which facilitates social relationships and reduces tension among people in a community. It is a form of verbal or non-verbal communication which plays an important role to enhance group cohesiveness (Hester, 2010), loyalty (Sukor et al., 2018) and attachment (Besser et al., 2012). Thus, it is assumed that humor could be the possible factor that may influence the student's sense of belonging to university. Humor generates positive sentiments among members of an interacting group or community by bonding them and reducing the external threat (Cruthirds, 2006; Hester, 2010).

Basically, there are four humor styles behavior which have been identified generally by Martin, Dorris, Larsen, Gray and Weir (2003). First is affiliative humor. It is a non-hostile humor which always life-affirming (Martin et al., 2003). People who use affiliative humor tend to say funny things, tell jokes and engage in spontaneous action to amuse others, enhance social relationship and decrease interpersonal tensions (Lefcourt, 2001). Second is self-enhancing humor. It illustrates tolerance and benevolence directed at self and others to deal with life's stress and misfortunes (Shirley, 2013). People with self-enhancing humor have a tendency to be amused by the incongruities of life and maintain the humor outlook even in the face of stress (Kuiper, Martin \& Olinger, 1993). Third is aggressive humor. It is a hostile humor that is used to promote oneself at other expense. Aggressive humor can be understood in terms of superiority theory which explains that people laugh when they feel superior from others. It includes satire and teasing which has constructive criticism delivered in a humorous way. Finally, self-defeating humor. It is characterized by self-disparaging commentary made at personal expense in order to be accepted by others (Martin et al., 2004). People who use this humor usually trying to raise their status by endearing themselves to others (Cruthirds, 2006). Previous study conducted by Cann, Norman, Welbourne and Calhoun (2008) found that humor styles behavior subsequently predicts the relationship satisfaction, attachment anxiety and avoidance. It is also significantly related to the social support (Schermer et al., 2015) and influenced the group cohesiveness and effective communication (Romero \& Cruthirds, 2006). Affiliative and self-enhancing humor styles was positively related to attachment and cohesion, meanwhile the aggressive and self-defeating humor styles were negatively related (Besser, Luyten \& Mayes, 2012; Hester, 2010). Basically, the sense of belonging could also bring the meaning of attachment and acceptance (Jones, 2009). It shows that humor styles behavior may have a direct relationship with personal sense of belonging to a community.

Upon further examination, humor may appear more dualistic in nature (Lelchook, 2010). In order words, humor may have different outcomes depend on the humor styles used. Humor can both enhance social cohesion or exclude individuals from groups, reduce or reinforce status differences, express agreement or disagreement, or help increase sociability and aggression (Martin, 2006). Besides the function to unite, there are also humor styles which can cause people to separate from each other (Meyer, 2000). It further explained by Martin et al. (2003) which divided the humor styles into two categories, first is adaptive (affiliative and self-enhancing) and second is maladaptive (aggressive and self-defeating) humor. Adaptive humor would increase the psychological well-being, whereas maladaptive humor would decrease the psychological well-being of undergraduate students (Martin et al., 2003). A considerable amount of research has confirmed that the effect of four humor styles on the emotional (anxiety, depression, stress) and psychosocial relationship falls into these two categories (Dozois \& Martin, 2009). In the current study, the sense of belonging is viewed as a fundamental need. It is expected that the strength of student's sense of belonging to the university may vary to the extent of their humor styles behavior. Therefore, this study will test several hypotheses regarding the influence of humor styles behavior on the sense of belonging.

H1 Affiliative humor will positively influence the sense of belonging.

H2 Self-enhancing humor will positively influence the sense of belonging.

H3 Aggressive humor will negatively influence the sense of belonging.

H4 Self-defeating humor will negatively influence the sense of belonging.

\subsection{METHODOLOGY}

In order to fill in the lack of research on humor styles behavior and its influence on the postgraduate students, the target population of this study was the local postgraduate students in a public university in Malaysia. The samples were selected using simple random sampling. This is a cross-sectional study which applied quantitative methods by distributing questionnaires to collect data. The survey packet may take about 10 minutes to complete. The questionnaires were distributed in person and through email. In total, 108 returned questionnaires were completely answered by the participants. The Humor Styles Questionnaire (HSQ) was used to measure the humor styles among postgraduate students. This instrument was developed by Martin et al. (2003). It measures four humor styles such as affiliative, selfenhancing, aggressive and self-defeating humor. The higher the score of each subscale, the greater the person identifies that particular dimension with their respective environment (Hester, 2010). The score of answer ranging from totally disagree (1) to totally agree (5). HSQ consists of 32-items with each question being self-descriptive statement of respondent's particular uses of humor. The four scales have moderate internal reliability with Cronbach alpha value ranging from 0.68 to 0.79 . The Psychological Sense of Belonging (SOBI-P) was used to measure student's sense of belonging to the university. This instrument has 18-items that employed 5-point scale ranging from strongly disagree (1) to strongly agree (5). It measured the psychological experience of valued involvement in a system or environment (Reilly \& Fitzpatrick, 2009). SOBI-P consists of three sub-constructs. They are peer acceptance, lecturer support and general sense of belonging (Hagerty \& Patusky, 1995). SOBI-P has a good internal consistency with the Cronbach alpha value of 0.81 . The descriptive statistics (mean and standard deviation) and inferential statistic (multiple regression) were conducted to achieve the research objectives.

\subsection{RESULTS}

Most of the respondents of current study are female (56\%) and studying at master's degree (66\%). The rest are male (44\%) and studying at doctoral degree (34\%). Further descriptive analysis was conducted on the research variables. Table 1 represents the level of humor styles 
and the sense of belonging among postgraduate students. It was found that most of the postgraduate students have a moderate level of humor styles except for aggressive humor. It seems that the postgraduate students have low tendencies to do aggressive humor in their social interaction $(\mathrm{M}=2.21, \mathrm{SD}=0.47)$. This study also found the moderate level of the sense of belonging among postgraduate students $(\mathrm{M}=3.02, \mathrm{SD}=0.38)$.

Table 1 Level of humor and sense of belonging

\begin{tabular}{lccl}
\hline Variables & Mean & Std. Deviation & Level \\
\hline Affiliative Humor & 2.94 & 0.49 & Moderate \\
Self-enhancing Humor & 2.77 & 0.50 & Moderate \\
Aggressive Humor & 2.21 & 0.47 & Low \\
Self-defeating Humor & 2.42 & 0.97 & Moderate \\
Sense of Belonging & 3.02 & 0.38 & Moderate \\
\hline
\end{tabular}

Result from regression analysis in Table 2 shows that, humor styles were significantly influenced the sense of belonging $\left(\mathrm{R}^{2}=0.246, \mathrm{~F}\right.$ $(2,62)=8.995, \mathrm{p}<0.01)$. For overall, the humor styles predict $24.6 \%$ of the sense of belonging among postgraduate students. Specifically, it was found that only self-enhancing humor and aggressive humor styles that have a significant influence on the sense of belonging. In which, the increase in 1 unit of self-enhancing humor will increase the sense of belonging to 0.317 units $(\beta=0.317, p<0.05)$. Meanwhile, the increase in 1 unit of aggressive humor will decrease the sense of belonging to 0.290 units $(\beta=0.290, p<0.05)$.

Table 2 Prediction of humor styles on sense of belonging.

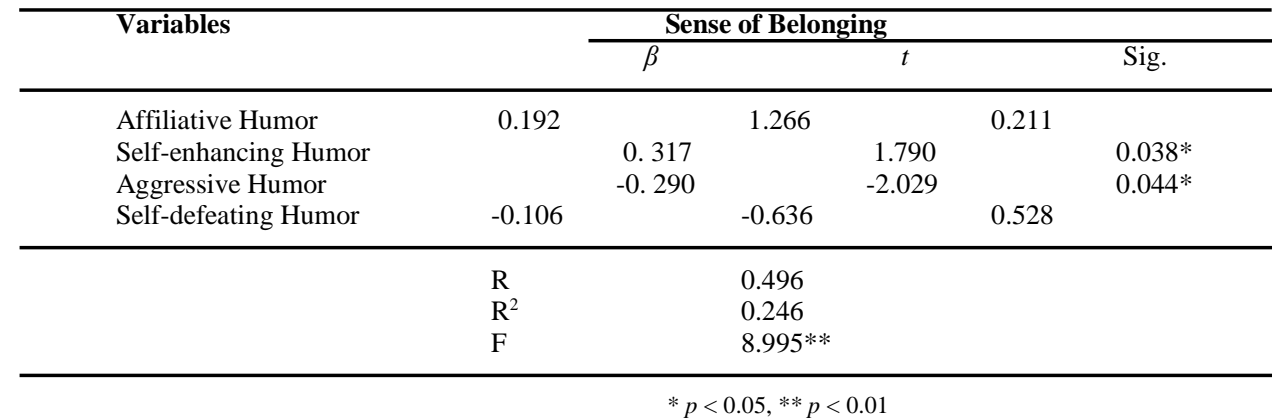

\subsection{DISCUSSION AND RECOMMENDATION}

The findings of current study revealed that postgraduate students have moderate tendencies to feel they belong to the university or being part of the university. It was found that the students perceived moderate level of support from lecturers and university staffs and tend to join the activities organized by the university. Thus, confirming the argument of earlier research by Lapidus (2004) on the existence of the sense of belonging among students in higher education. It further supports the Maslow's hierarchy of need theory which argued that the sense of belonging is the natural need for all groups of people.

Besides that, the study also found the moderate level of affiliative, self-enhancing and self-defeating humor among university postgraduate students. The findings prove the presence of humor behavior among students in high educational learning environment concurred with previous researchers such as Carrica (2009), Dozois, Martin and Bieling (2009), Fitts et al. (2009), Kuiper and McHale (2009), Sukor and Shah (2016), Yip and Martin (2005) which point out the different humor styles behavior among students in higher education. Despite that, the current study showed the low tendency of postgraduate students to do aggressive humor. Perhaps the students are aware that the aggressive humor may have negative impact on the social relationship as the behavior less appreciated by other students in the university.

The current study found that humor styles behavior have significant influence on the student's sense of belonging to the university. The finding confirms the previous research by Alkan (2014) which found that the use of humor as a coping strategy has strengthened the sense of membership and acceptance towards university, which in turn predicted the intention to drop out from the university. It means that humor can affect the student's bonding to the university in the way that it provides the opportunity for students to being part of the university and promotes the intention to stay on the same university in the future.

Upon further analysis, it was found that the self-enhancing humor has a significant positive influence on the sense of belonging. Thus, accepting the hypothesis $\mathrm{H} 2$ of the study which stated that the self-enhancing humor will enhance the student's sense of belonging to the university. The finding suggests that the students who can maintain the humorous outlook even in the face of stress or making joke to relieve stress are more likely to experience community and peer acceptance, lecturer support, positive sense of belonging to the university and less likely to feel lonely. As previously mentioned by Tucker et al. (2013) those who naturally use self-enhancing humor are less likely to experience suicidal thought and thwarted belonging. The finding also in accordance with previous study by Hester (2010) which found that self-enhancing humor has a positive relationship with group cohesiveness, sense of belonging and positive emotion. Despite its function to cope with stress, self-enhancing humor could also increase individuals sense of belonging towards a group or community, establish group identity, increase work performance (Hester, 2010) and increase social support (Schermer et al., 2015). Shirley (2013) has further categorized the self-enhancing humor as a positive humor due to its positive effect on cheerfulness, self-esteem, psychological 
prosperity and social relationship satisfaction. The use of self-enhancing humor may allow the enhancement of individual's tenuous feeling of self-worth and perhaps prevent them from loneliness and increase their sense of belonging to the university.

Moreover, result of the study supports the negative relationship between aggressive humor and sense of belonging. It was found that the aggressive humor would decrease the sense of belonging among postgraduate students, thus accepting the hypothesis $\mathrm{H} 3$ of the study. The students who tend to use humor to tease and ridicule others are less likely to have peer acceptance, lecturer support and experience low level of engagement to the university. This assertion was supported by consistent findings from previous researchers that associate the aggressive humor with negative variables such as attachment anxiety and avoidance (Besser, Luyten \& Mayes, 2012), stress and group isolation (Hester, 2010), dysfunctional competition in group or community (Terrion \& Ashforth, 2002) and depression (Erickson \& Feldstein, 2007). The aggressive humor has a tendency to push others away, caused isolation in a community or loneliness because it makes the social connections difficult with those who did not use aggressive humor style (Tucker et al., 2013). As a result, the student's feeling of acceptance and engagement to the university is decreasing. The finding of current study also supports the previous study by Dozois et al. (2009) which found that the aggressive humor predicts low satisfactory interpersonal relationship to a community, because it is correlated negatively with relationship variables such as relationship satisfaction, interpersonal competence, agreeableness, belongings and conscientiousness.

Contrary to the expected result, affiliative humor and self-defeating humor did not display a significant association with the sense of belonging. The result did not support the hypothesis H1 and H4. The use of humor either to amuse others or to hide the negative feelings from others seem to be not significantly influence the student's sense of belonging to the university, whereas the tendency to gain peer acceptance and teacher support still maintained. Perhaps the insignificant result means that the affiliative and self-defeating humor were underutilized by postgraduate students or it may always be used alongside other types of humor in student's daily communication. Therefore, its existence in the learning environment may not be enough to cause significant changes to the student's sense of belonging towards the university.

For overall, the result of current study suggests that the use of self-enhancing humor would increase the student's engagement to the university and the tendency to feel they belong to the university. Meanwhile, the use of aggressive humor would decrease the feeling of acceptance, support and attachment to the university. The result partly supported the relationship between humor styles and sense of belonging. Self-enhancing humor demonstrates higher influence on the sense of belonging compared to aggressive humor. It further shows that humor has more positive influence rather than negative influence on the sense of belonging.

Despite all the findings, the present study has several limitations. The study was limited to university postgraduate students. Future studies should consider wider samples varieties with larger sample size including the undergraduates and the university staff so that the result can be generalized to all members of the university. Instead of cross-sectional research design, future researchers should consider longitudinal research design in order to achieve complete understanding about the impact of humor on the sense of belonging as it may change across time. Another possible limitation is the role of individual characteristics. This study didn't explore the individual differences and its possible influence as the third variables of humor behavioral outcome. Future studies should consider how individual differences may influence the impact of humor styles on the sense of belonging. As mentioned by Romero and Cruthirds (2006) individual differences in term of gender and ethnicity may become the moderator that can affect the relationship between humor styles behavior and the desired outcome.

\section{ם6.0 CONCLUSION}

Since humor has its own part in human interpersonal communication and social interaction, studying humor and its impact on social relationship variable would be beneficial for relationship satisfaction and well-being among university postgraduate students. The study contributes to the literature by demonstrating that humor styles behavior influences the student's feeling of acceptance and engagement to the university. The current study also supports Martin's humor styles behavior theory which argues that some humor styles behavior might be beneficial and some might be deleterious to health and social relationship. It is possible that the university administrator could use the findings to predict the student's social satisfaction, acceptance and involvement towards university through their humor styles behavior. The study further suggests that the postgraduate's committee and manager could enhance the postgraduate student's engagement to the university as well as their feeling of being part of the university by encouraging the self-enhancing humor and hampering the aggressive humor if possible. It is clear from the findings that in order to design an effective retention program or to increase the sense of belonging especially among local postgraduate students, a university need to take on the non-academic factors such as humor to create a more cheerful, friendly and hospitable learning environment.

\section{References}

Alkan, N. (2014). Humor, Loneliness And Acceptance: Predictors Of University Drop-Out Intentions. Procedia-Social and Behavioral Sciences, 152 , $1079-1086$.

Anderman, L. H., \& Anderman, E. M. (1999). Social Predictors Of Changes In Students' Achievement Goal Orientations. Contemporary Educational Psychology, 24(1), 21-37.

Bernard, H. R. (2011). Research Methods In Anthropology (Qualitative And Quantitative Approach). United Kingdom: AltaMira Press.

Besser, A., Luyten, P., \& Mayes, L. C. (2012). Adult Attachment And Distress: The Mediating Role Of Humor Styles. Individual Differences Research, 10(3), 153164.

Blonstein, C. H. (2004). Social Anxiety As Moderator And Social Self-Efficacy As Well As Sense Of Belonging As Mediators In The Social Stress-Depression Relationship (Doctoral Dissertation). Available from ProQuest Dissertation and Theses. (UMI NO. 3132461).

Cann, A., Norman, M. A., Welbourne, J. L., \& Calhoun, L. G. (2008). Attachment Styles, Conflict Styles And Humour Styles: Interrelationships And Associations With Relationship Satisfaction. European Journal of Marketing, 22, 131-146.

Carrica, J. L. (2009). Humor Styles and Leadership Styles: Community College Presidents (Doctoral Dissertation). Available from ProQuest Dissertation and Theses Database. (UMI No. 3400987).

Cedeno, L. A. (2010). An examination Of The Mutual Impact Of Students'Sense Of School Belonging And Adjustment In A Sample Of Urban, Ethnic- $\quad$ Minority, Elementary-Aged Students (Doctoral Dissertation). Available from ProQuest Dissertation and Theses. (UMI NO. 3434748). 
Cherry, K. (2018). The Five Levels of Maslow's Hierarchy of Needs. How Maslow's Famous Hierarchy Explains Human Motivation. Medically Reviewed Article. Retrieved from www.verywellmind.com. Access date: 4 Nov 2018

Corner, J. P. (2004). Leave No Child Behind Preparing Today's Youth For Tomorrow's World. New Haven, CT, US: Yale University Press.

Cruthirds, K. W. (2006). The Impact of Humor on Mediation. Dispute Resolution Journal, 61(3), 32-41.

Davis, H. A. (2003). Conceptualizing the Role And Influence Of Student-Teacher Relationships On Children's Social And Cognitive Development. Educational Psychologist, 38(4), 207-234.

Dozois, D. J. A., Martin, R. A., \& Bieling, P. J. (2009). Early Maladaptive Schemas And Adaptive/Maladaptive Styles Of Humor. Cognitive Therapy Research, 33, 585-596.

Erickson, S. J., \& Feldstein, S. W. (2007). Adolescent Humor And Its Relationship To Coping, Defense Strategies, Psychological Distress And Well-Being. Child Psychiatry Humor Development, 37, 255-271.

Fitts, S. D., Sebby, R. A., \& Zlokovich, M. S. (2009). Humor Styles As Mediators Of The Shyness-Loneliness Relationship. North American Journal of Psychology, 11(2), 257-272.

Freeman, T. M. (2005). Sense of Belonging In Higher Education: Relations To Instructor Practice, Motivation And Achievement (Doctoral Dissertation). Available from ProQuest Dissertation and Theses. (UMI NO. 3200324).

Goodenow, C. (1993a). Classroom Belonging Among Early Adolescent Students: Relationships To Motivation And Achievement. The Journal of Early Adolescent, 13(1), 21-43.

Goodenow, C. (1993b). The Psychological Sense Of School Membership Among Adolescents: Scale Development And Educational Correlates. Psychology in the Schools, 31(1), 79-90

Goodenow, C., \& Grady, K. (1993). The Relationship Of School Belonging And Friends' Values To Academic Motivation Among Urban Adolescent Students. Journal of Experimental Education, 62(1), 60-71.

Hagerty, B.M.K., \& Patusky, K.L. (1995). Developing a Measure Of Sense Of Belonging. Nursing Research, 4, 9-13.

Hall, K. (2014). Create a Sense Of Belonging: Finding Ways To Belong Can Help Ease The Pain Of Loneliness. Retrieved from psychologytoday.com. Access date: 20 October 2017

Hale, C., Hannum, J., \& Espelage, D. (2005). Social Support And Physical Health: The Importance Of Belonging. Journal of American College Health, 53(6), 276284.

Hawkins, D. A. (2008). Comparing the Use Of Humor To Other Coping Mechanism In Relation to Maslach's Theory of Burnout (Doctoral Dissertation). Available from ProQuest Dissertation and Theses. (UMI No. 3322923). Access date: 12 Mei 2017

Hester, N. T. (2010). The Examination Of Humor Usage And Its Relationship To Cohesion In Male Collegiate Basketball. University of North Carolina, Greensboro.

Holmes, J., \& Marra, M. (2006). Humor and leadership Style. Humor, 19(2), 119-138

Jones, R. C. (2009). Sense of Belonging And Its Relationship With Quality Of Life And Symptom Distress Among Undergraduate College Students (Doctoral Dissertation). Available from ProQuest Dissertation and Theses. Access date: 2 September 2017

Kia-Keating, M., \& Ellis, B. H. (2007). Belonging and Connection To School In Resettlement: Young Refugees, School Belonging And Psychosocial Adjustment. Clinical Child Psychology and Psychiatry, 12(1), 29-43.

Kuiper, N. A., Martin, R. A., \& Olinger, L. J. (1993). Coping Humour, Stress And Cognitive Appraisals. Canadian Journal of Behavioral Science, $25,81-96$.

Kuiper, N. A., \& McHale, N. (2009). Humor Styles as Mediators between Self-Evaluative Standards and Psychological Well-Being. The Journal of Psychology, 143(4), 359-376

Langin, K. (2019). A Sense Of Belonging Matters. That's Why Academic Culture Needs To Change. American Association for the Advancement of Science.

Lang, J. C., \& Lee, C. H. (2010). Workplace Humor And Organizational Creativity. The International Journal of Human Resource Management, 21(1), 46-60.

Lapidus, R. B. (2004). An Evaluation Of A High School-Based Group Mentoring Program on Proteges Sense Of Belonging (Doctoral Dissertation). Available from ProQuest Dissertation and Theses. (UMI No. 3170736). Access date: 2 September 2017

Lefcourt, H. M., Davidson, K., Prkachin, K. M., \& Mills, D. E. (1997). Humor as A Stress Moderator In The Prediction Of Blood Pressure Obtained During Five Stressful Tasks. Journal of Research in Personality, 31(4), 523-542.

Lefcourt, H. (2001). Humor: The Psychology Of Living Buoyantly. New York: Plenum.

Lelchook, A. (2010). The Use Of Humor By Leaders In Response To Situational Stressors (Doctoral Dissertation). Available from ProQuest Dissertation and Theses. (UMI No. 1474720).

Mak, B. C. N., Liu, Y., \& Deneen, C. C. (2012). Humor in The Workplace: A Regulating And Coping Mechanism In Socialization. Discourse \& Communication, 6 , 163-179.

Martin, R. A., Doris, P. P., Larsen, G., Gray, J., \& Weir, K. (2007). The Psychology Of Humor: An Integrative Approach. Burlington, USA: Elsevier.

Martin, R. A., Doris, P. P., Larsen, G., Gray, J., \& Weir, K. (2004). Sense of Humor And Physical Health: Theoretical Issues, Recent Findings And Future Direction. Humor, 17, 1-19.

Martin, R. A., Dorris, P. P., Larsen, G., Gray, J., \& Weir, K. (2003). Individual Differences In Uses Of Humor And Their Relation To Psychological Well-Being Development of the Humor Styles Questionnaire. Journal of Research in Personality, 37, 48-75.

Martin, R. A. (2006). The Psychology of Humor: An Integrative Approach. Boston, MA: Elsevier Academy Press.

Maslow, A. (1954). Motivation and Personality. New York: Harper.

McMillan, D. W., \& Chavis, D. M. (1986). Sense Of Community: A Definition And Theory. Journal of Community Psychology, 14(1), 6-23.

Meyer, J. C. (2000). Humor as a Double- Edged Sword: Four Functions Of Humor In Communication. Communication Theory, 10(3), 310-331

Reilly, J. E. R., \& Fitzpatrick, J. J. (2009). Perceived Stress And Sense Of Belonging In Doctor Of Nursing Practice Students. Journal of Professional Nursing, 25(2), 81-86.

Romero, E. J., \& Cruthirds, K. W. (2006). The Use Of Humor In The Workplace. The Academy of Management Perspectives, 20(2), 58-69.

Schermer, J. A., Martin, R. A., Martin, N. G., Lynskey, M. T., Trull, T. J., Vernon, P. A. (2015). Humor Styles And Borderline Personality. Personality and Individual Differences, 87, 158-161.

Shirley, J. D. (2013). Effect of Humor On Teacher Stress, Affect And Job Satisfaction (Doctoral Dissertation). Available from ProQuest Dissertation and Theses. (UMI NO. 3565886).

Singh, A. (2018). Investigating the Sense Of Belonging Of International Students Through A Predictive Model. Graduate Theses and Dissertation. Retrieved from digirep@iastate.edu.

Sukor, M. S. M., Shah, I. M. (2016). Gaya Tingkahlaku Humor Dalam Kalangan Pelajar Pasca Ijazah Fakulti Pengurusan. Jurnal Kemanusiaan, $14(3), 74-86$.

Sukor, M. S. M., Shah, I. M., \& Panatik, S. A. (2018). Pengaruh Humor Self-Enhancing Ke Atas Hubungan Antara Stres Kerja Dan Kesetiaan Organisasi. Jurnal Pengurusan, 53, 159-168.

Terrion, J. L., \& Ashforth, B. E. (2002). From "i" to "we": The Role Of Putdown Humor And Identity In The Development Of A Temporary Group. Human Relations, $55(1), 55-88$.

Todman, V., \& Hume, S. (2018). Sense of Belonging And Social Capital: Our Hot Topics for 2018/19. Social Mobility \& Student Success. Behavioural Insights. WordPress Theme. Retrieved from https://blogs.kcl.ac.uk.

Tucker, R. P., Wingate, L. R., O'Keefe, V. M., Slish, M. L., Judah, M. R., \& Kerswill, S. R. (2013). The Moderating Effect Of Humor Style On The Relationship Between Interpersonal Predictors Of Suicide And Suicidal Ideation. Personality and Individual Differences, 54, 610-615.

Westerfield, T. S. (2009). The Effect Of Looping And Teaming On Rural Black Middle School Students' Sense Of Belonging. Mississippi State University, Mississippi. Yip, J. A., \& Martin, R. A. (2006). Sense of Humor, Emotional Intelligence And Social Competence. Journal of Research in Personality, 40, $1202-1208$. 